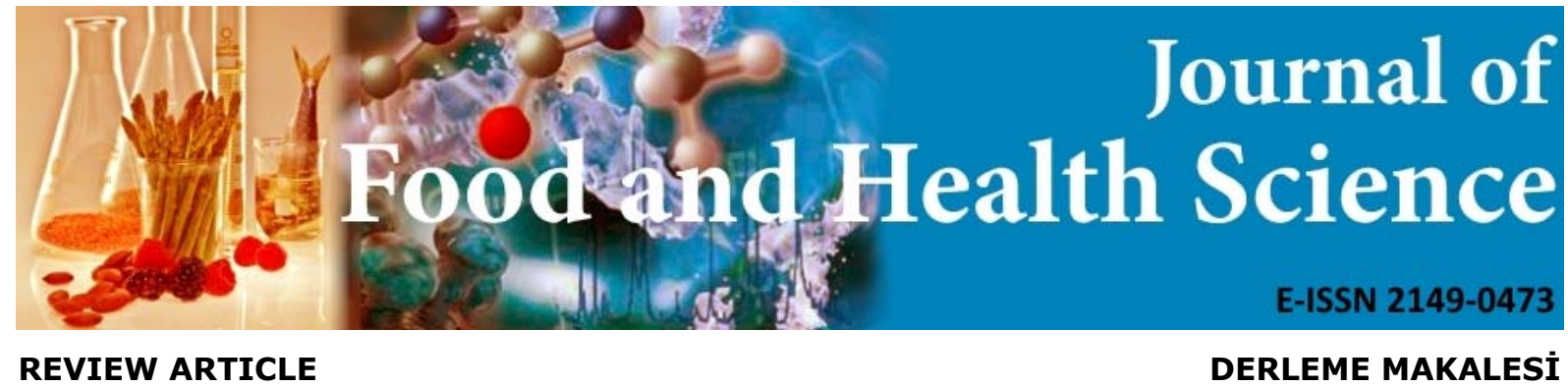

\title{
BLACK CUMIN (Nigella sativa) AND ITS ACTIVE COMPONENT OF THYMOQUINONE: EFFECTS ON HEALTH
}

\author{
Merve Şeyda Karaçil Ermumcu ${ }^{1}$ ORCID ID: $\underline{0000-0002-2023-8433}$, \\ Nevin Şanlıer ${ }^{2}$ ORCID ID: $\underline{0000-0001-5937-0485}$ \\ ${ }^{1}$ Gazi University, Faculty of Health Sciences, Nutrition and Dietetics Department, Ankara, Turkey \\ ${ }^{2}$ Biruni University, Faculty of Health Sciences, Nutrition and Dietetics Department, İstanbul, Turkey
}

Received: 18.04 .2017

Accepted: 23.06 .2017

Published online: 22.09.2017
Corresponding author:

Merve Şeyda KARACIL ERMUMCU, Gazi University, Faculty of Health Sciences, Nutrition and Dietetics Department, Ankara, Turkey

E-mail: merveseyda@gmail.com

\begin{abstract}
:
Nigella sativa has the richest historical past of plants in the healthcare field. It has been used as a food preservative and to enhance flavour in many countries of the world for thousands of years and has also been used as a spice, and Nigella sativa seed and oil has been consumed for the treatment of many diseases in the world for many years. Today, it is believed to have antihypertensive, antihyperlipidemic, antidiabetic, anticancer, antioxidant, antimicrobial, antitumour, antibacterial, anti-inflammtory and immune-system effects through its components. And therefore Nigella sativa and its effects on health are discussed in this review.
\end{abstract}

Keywords: Nigella sativa, Black cumin,

Thymoquinone, Nutrition, Health 


\section{J ournal abbreviation: J Food Health Sci}

\section{Introduction}

Nigella sativa is a plant that is grown worldwide primarily in the Middle East, Mediterranean regions, Southern Europe, India, Pakistan, Syria, Saudi Arabia, and Turkey. For centuries, medicinal plants have taken part in the treatment of many diseases in various medicinal branches and also in traditional medicine (S. Ahmad \& Beg, 2013). Nigella sativa has been widely used for more than two thousand years as a curative and preventive substance against many diseases in Central Asia and some other Asian countries (BAYRAM; Razavi \& Hosseinzadeh, 2014). Nigella sativa is acknowledged to be a miraculous plant due to its rich history and religious background (S. Ahmad $\&$ Beg, 2013) and N. sativa is given even greater importance especially in Islamic countries, due to its many different beneficial properties (Razavi \& Hosseinzadeh, 2014).

Nigella sativa has been widely used from the past to the present for various purposes, including as a painkiller, and for anthelmintic, as an appetiser, and for carminative, sudorific, digestive, diuretic, emmenagogue, guaiacol, antifebrile, galactagouge and cathartic uses. Nigella sativa is reported to decrease asthenia and depression, and to increase body resistance (Razavi \& Hosseinzadeh, 2014).

It has also been highlighted that the active substances of $N$. sativa have antibacterial, antifungal, antidiabetic, immunomodulator, anti-inflammatory, analgesic, antiviral, antioxidant, anticonvulsant, antihypertensive, anticancer and antihyperlipidemic effects (Entok et al., 2014; Leong, Rais Mustafa, \& Jaarin, 2013; Shafiq, Ahmad, Masud, $\&$ Kaleem, 2014; Singh et al., 2014). Due to these effects, $N$. sativa seed and oil have been used globally in the treatment of many diseases such as asthma, diarrhoea, dysentery, dyspepsia, fever, icterus, apoplexy, hemorrhoids and cardiovascular, digestive, immune-system, liver, respiratory and kidney diseases (Forouzanfar, Bazzaz, \& Hosseinzadeh, 2014). However, scientific evidence is required to explain and corroborate the mechanism of action for the given positive effects of $\mathrm{N}$. sativa. This review presents the effects of $\mathrm{Ni}$ gella sativa and its active component, thymoquinone, on various diseases such as cardiovascular disease in particular and Type 2 Diabetes Mellitus (DM), obesity and cancer, with supportive studies in humans and animals.

\section{History of Nigella sativa}

It has been highlighted that $N$. sativa has the richest and most mystical history among all the plants used in medicine. The $N$. sativa oil sample that was discovered in the remnants of Tutankhamun's tomb is indicative of its use since ancient times. It is reported that $N$. sativa seed and oil were used by Hippocrates to strengthen the liver, to solve problems related to the digestive system, to treat snake and scorpion stings, abscesses, skin rashes, infections in the head, and the common cold. It has also been suggested that in later years, Penedius Dioscorides used $N$. sativa oil to relieve headache and toothache, to clear nasal congestion and to destroy enterozoa. $N$. sativa oil is also stated to have been used for treatment by Ibni Sina to stimulate the metabolism and to relieve asthenia and lethargy (Botnick et al., 2012; Salem, 2005; Tembhurne, Feroz, More, \& Sakarkar, 2014). Religious statements also highlight the important properties of black cumin. The oil obtained from this plant is known to have been used by Cleopatra, the Queen of Egypt, for health and beauty (Lord, Sekerovic, \& Carrier, 2014; Paarakh, 2010). Today, the black cumin seed and oil are assumed to be an indispensable source in alternative medicine for the treatment and prevention of various diseases (Botnick et al., 2012; Lord et al., 2014).

\section{Nigella sativa and its Chemical Composition}

The black cumin plant is generally grown in Western Asia, in Middle Eastern countries and in the Konya region in Turkey (Lord et al., 2014). Black cumin, which is usually used as a spice, is grown as twelve different types; the most widely used type in agriculture and trade is $N$. sativa, on which, as indicated, many studies have been conducted worldwide (Yakup, 2007). Black cumin, N. sativa, which belongs to the Ranunculacea (Buttercup) family, is also known as black seed (Güllü \& Gülcan, 2013). It is a rather pilous annual herbaceous plant with a height of approximately 20-30 $\mathrm{cm}$. Its flower is five-leaved and is light or dark blue. The part that is used for nutrition is the seed, which consists of many white, trigonal and bitter grains with a special aroma inside the capsule (Salem, 2005). The chemical compound of the $N$. sativa seed, with a bitter taste, differs depending on the harvest season and type of plant, as well as on the climate and region where it grows (Bulca, 2015; Güllü \& Gülcan, 2013; Heshmati \& Namazi, 2015; Yakup, 2007). The $N$. sativa seed, 
J ournal abbreviation: J Food Health Sci

depending on the region, contains volatile $(0.40 \%-0.45 \%)$ and non-volatile $(32 \%-40 \%)$ oils, protein $\quad(16.00 \%-20.85 \%)$, carbohydrates (31.0\%-33.9\%), fibre (5.50-7.94\%), alkaloids, tannins, saponins, minerals such as iron, calcium, potassium, magnesium, zinc and copper $(1.79 \%$ $3.44 \%$ ), vitamin $\mathrm{A}$ and $\mathrm{C}$, thiamine, niacin, pyridoxine and folate (Al-Mahasneh, Ababneh, \& Rababah, 2008; Güllü \& Gülcan, 2013; Salama, 2010; Sultan et al., 2009). Nigella sativa is also rich in unsaturated and essential fatty acids and studies indicate that the volatile oil content ranges from $0.4 \%$ to $2.5 \%$ (Hosseinzadeh \& Parvardeh, 2004; Ramadan \& Moersel, 2004; Sultan et al., 2009). Volatile oil contains active basic components such as thymoquinone, dithymoquinone and thymohydroquinone (Güllü \& Gülcan, 2013; Kaya, Kara, \& Özbek, 2003). Studies indicate that $N$. sativa seeds and its components have a positive effect on health. Thymoquinone is the most studied of the black cumin components and researchers have aimed to clarify the mechanisms by which thymoquinone plays a role in the prevention and treatment of disease (S. Ahmad \& Beg, 2013; Akash et al., 2011; Ilaiyaraja \& Khanum, 2010; Paarakh, 2010; Randhawa \& Alghamdi, 2011).

\section{Thymoquinone: the Basic Active Substance of Nigella sativa}

Nigella sativa can be used in various forms, as a powder, oil or extract in traditional treatment (Heshmati \& Namazi, 2015; Heshmati, Namazi, Memarzadeh, Taghizadeh, \& Kolahdooz, 2015). Thymoquinone, which is one of the most important bioactive components of $N$. sativa and is responsible for its many biological effects, was first synthesised in 1959 and it was reported that thymoquinone exists as a volatile oil in a proportion of $18.4 \%-24.0 \%$ (Ali \& Blunden, 2003; Burits \& Bucar, 2000; Yüncü, Sahin, Bayat, \& İbrahim, 2013). Other analyses have indicated that the concentration of thymoquinone is $52.6 \mathrm{mg} / 100$ $\mathrm{g}$ and $20.13 \mathrm{mg} / 100 \mathrm{~g}$ (Tüfek, Altunkaynak, Altunkaynak, \& Kaplan, 2015).

\section{Effects of Nigella sativa on Health}

A wide range of studies have been conducted concerning the biological activities and curative properties of black cumin (S. Ahmad \& Beg, 2013). Nigella sativa is used in the treatment of many diseases in many countries globally. Its beneficial effects on health, especially against diseases such as cancer, diabetes and cardiovascular disease have been highlighted (Bamosa, 2015; Entok et al., 2014; Leong et al., 2013; Shafiq et al., 2014; Singh et al., 2014). The effects of $N$. sativa on health are shown in Figure 1.

\section{Cardiovascular Health Benefits of Nigella sa- tiva}

Cardiovascular disease is among the top causes of death worldwide and is thus deemed to be an important public health concern. Therefore, current strategies are being developed for its prevention and treatment. Changes in lifestyle and increases in the prevalence of obesity especially increase the incidence of cardiovascular disease. Hypertension, atherosclerosis, a high cholesterol level and other metabolic diseases are among the contributory factors of cardiovascular disease. Weight control and restoring the lipid profile play an important role in the prevention of the disease. Dieting has an important role in both these aims and complementary and alternative treatments have also gained in popularity in recent years (Mahdavi, Namazi, Alizadeh, \& Farajnia, 2015). Although $N$. sativa is stated to have positive effects on lipid profile and cardiovascular disease, other studies present different results in terms of metabolic indicators (S Bourgou, Pichette, Marzouk, \& Legault, 2010; Datau, Surachmanto, Pandelaki, \& Langi, 2010; Dehkordi \& Kamkhah, 2008; Houcher, Boudiaf, Benboubetra, \& Houcher, 2007; Shafiq et al., 2014; Shahzad \& Nasiruddin, 2011). 
Figure 1. Health benefits of Nigella sativa.

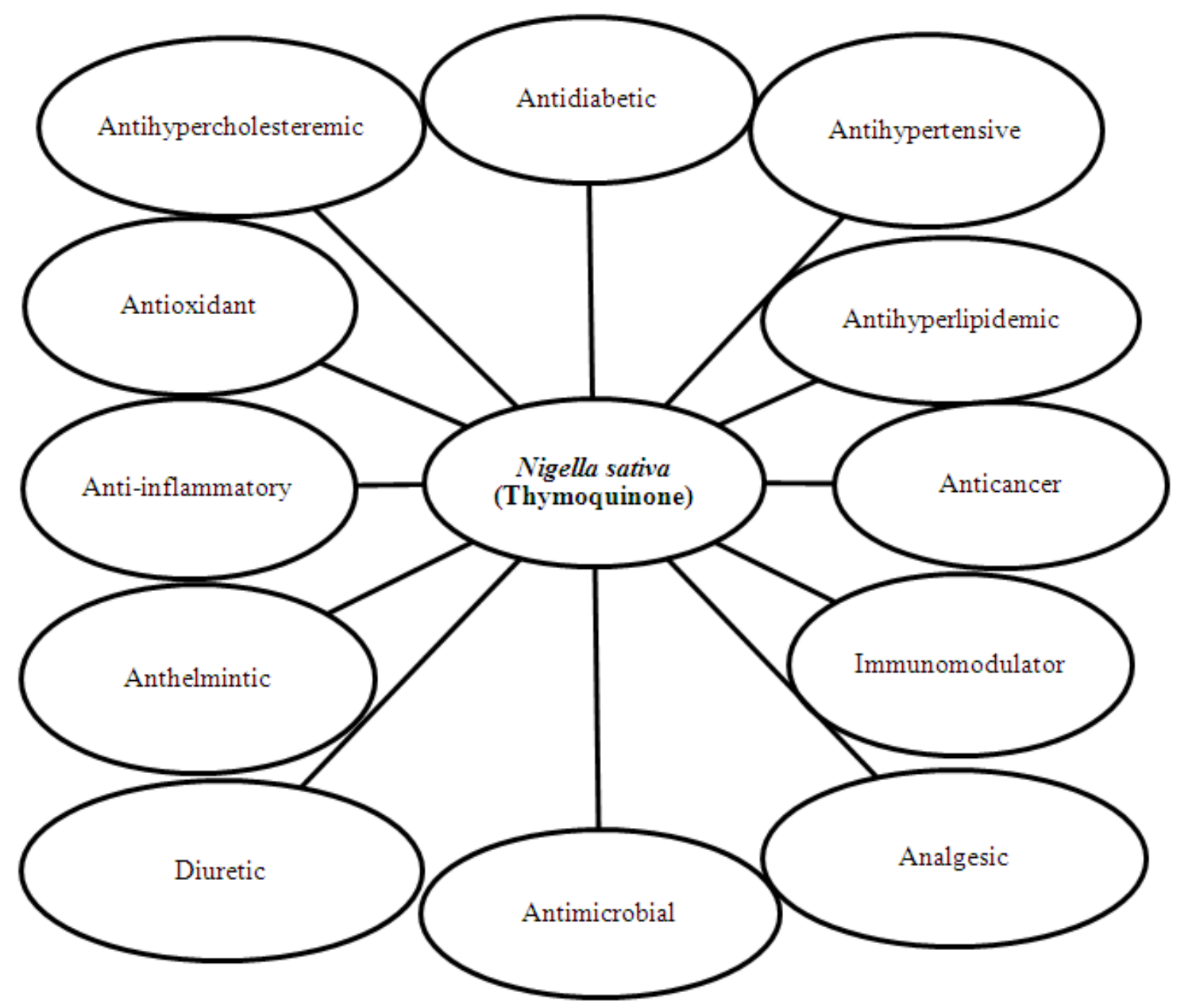

The effects that Nigella sativa has on cardiovascular diseases are as follows:

\section{Antioxidant Properties of Nigella sativa}

Analysis of the antioxidant content of $N$. sativa has indicated that $N$. sativa has a higher content of volatile-oil antioxidants than non-volatile oil antioxidants (Sultan et al., 2009). When the antioxidant capacities of $N$. sativa grown in different regions (Egypt and Samsun, for instance) were analysed, they were found to be more active than synthetic antioxidants (Yakup, 2007). It is proposed that the $N$. sativa extract grown in Tunisia can be used as a natural antioxidant in in vitro and ex vitro environments, and as a food additive to prevent the organoleptic deterioration that occurs due to free radicals (Soumaya Bourgou, Pichette, Marzouk, \& Legault, 2012). Another study on antioxidant capacity focused on the positive effects of thymoquinone, the basic bioactive component of volatile oil, and demonstrated that the antioxidant effect of thymoquinone plays a large part in the mechanism of action of the volatile oil (S Bourgou et al., 2010). According to many studies, the potential antihyperglycemia and antihyperlipidemia properties of $N$. sativa are based on its antioxidant content (Al-Mahasneh et al., 2008; Bamosa, Kaatabi, Lebda, Elq, \& Al-Sultan, 2010; Ragheb et al., 2008). Thymoquinone and dithymoquinone are amongst the main antioxidant components of $N$. sativa. The intake of $N$. sativa in all forms develops the antioxidant defence capacity of the body. 


\section{J ournal abbreviation: J Food Health Sci}

Some studies indicate that $N$. sativa decreases lipid peroxidation and increases antioxidant enzymes (Al-Mahasneh et al., 2008; Ragheb et al., 2008). It is thought that a decrease in oxidative stress renews the pancreatic beta-cells, maintains the integrity of beta-cells, increases the number and volume of islet cells, decreases insulin resistance and increases insulin secretion, and aids glycation end-product inhibition. The glycaemic improvement resulting from the mentioned positive effects of $N$. sativa is thought to relieve lipid dysfunction, especially in diabetics. Furthermore, a decrease in free radicals affects lipid metabolism directly and indirectly; antioxidant components can improve enzyme functions in lipid metabolism by protecting cells against lipid peroxidation (Bamosa et al., 2010; Heshmati \& Namazi, 2015).

Many studies on humans and animals have shown that $N$. sativa and its active component thymoquinone have positive effects by decreasing levels of serum lipids, total cholesterol (TC), triglycerides (TG) and low-density lipoproteins (LDL), whereas other studies have suggested that $N$. sativa and thymoquinone have no effect (Bamosa, Ali, \& al-Hawsawi, 2002; Nader, El-Agamy, \& Suddek, 2010; Ragheb et al., 2008). However, no definite results have demonstrate that they increase the level of high-density lipoproteins (HDLs), which play an active role in decreasing the risk of cardiovascular disease, in particular (Razavi \& Hosseinzadeh, 2014).

In a study that examined the effect of $N$. sativa seed and oil on its anti-atherogenic potential in rabbits that were fed with a hypercholesteremic diet, 25 rabbits were divided into five groups. Four groups were determined as hypercholesteremic and the other group as negative normal. One of the hypercholesteremic groups was separated as a positive control group, and was fed with a diet containing $1 \%$ cholesterol for 3 weeks. During the final 8 weeks, $1 \mathrm{~g} / \mathrm{kg} N$. sativa powder, $0.5 \mathrm{~g} / \mathrm{kg} N$. sativa oil or $10 \mathrm{mg} /$ day simvastatin were added, respectively, to the diet of each the groups except the positive control group. It was found that weight, plasma TC and LDL increased considerably, whereas there was no significant different in the HDL level in the group fed on a diet with $1 \%$ cholesterol, compared to the negative control group. On the other hand, plasma TC, TG and LDL levels considerably decreased in the groups whose diets contained $N$. sativa oil and seed, compared to levels in the positive group (Al-Naqeep, Al-Zubairi, Ismail, Amom, \& Esa, 2011). Similar to these results, intake of $10 \mathrm{mg} / \mathrm{mL}$ thymoquinone by gavage positively affected blood lipids in rats that were fed an atherogenic diet for 30 days (S. Ahmad \& Beg, 2013). In a study conducted to examine the effects of different doses of $N$. sativa supplement on the serum lipid profile in rats, 15 rats were separated as a control group and 60 rats were fed with $N$. sativa supplement. Either 100 $\mathrm{mg}, 200 \mathrm{mg}, 400 \mathrm{mg}$ and $600 \mathrm{mg}$ per $\mathrm{kg}$ were given daily to rats for four weeks, which resulted in a significant decrease in total cholesterol level (Kocyigit, Atamer, \& Uysal, 2009). In another study, individuals with type $2 \mathrm{DM}$ were separated into three groups and were given $N$. sativa at a rate of 1, 2, $3 \mathrm{~g}$ /day for twelve weeks. Individuals who were given $N$. sativa at minimum level $(1 \mathrm{~g} /$ day $)$ and a maximum level ( $2 \mathrm{~g}$ /day and $3 \mathrm{~g} /$ day $)$ were compared. After twelve weeks, plasma TG, TC and LDL cholesterol levels were significantly lower in individuals given $2 \mathrm{~g} /$ day $N$. sativa, and the most positive effects occurred in those who took $2 \mathrm{~g}$ /day. This study, therefore, determined that increasing the amount of $N$. sativa has no positive effective on individuals' lipid profiles (Kaatabi, Bamosa, Lebda, Al Elq, \& Al-Sultan, 2012). In a follow-up study conducted on premenopausal women, individuals were given either a placebo or 1,600 mg N. sativa powder and the lipid profile of the groups was then examined. No significant changes in the lipid profile values of the placebo group were observed, compared to the initial level after 12 weeks. Additionally, no significant decrease in LDL and TG levels were found, compared to the initial level in the group treated with black cumin; however, the total cholesterol level was considerably lower. Significant decreases in the blood pressure were also observed, which is a risk factor for cardiovascular disease (Latiff, Parhizkar, Dollah, \& Hassan, 2014).

In a study in which menopausal women were given $1 \mathrm{~g}$ /day $N$. sativa powder after breakfast for two months, the weight of women decreased compared with that of the control group, although the difference was not statistically significant; however, their TC, TG, LDL and HDL levels considerably improved (Ibrahim et al., 2014). Therefore, it has been claimed that intake of $N$. sativa in different forms can be used as a supportive for drugs that decrease the lipid profile (Razavi \& Hosseinzadeh, 2014). 


\section{J ournal abbreviation: J Food Health Sci}

\section{Antihyperlipidemic and Antihypercholestere- mic Effects of Nigella sativa}

Hypercholesterolemia is reflected by an increase in TG, TC, LDL, HDL and very low-density lipoprotein (VLDL) levels (S. Ahmad \& Beg, 2013). An increase in the HDL level and a decrease in the LDL level in the circulation have positive effects on reducing the risk of cardiovascular disease (Mani \& Rohatgi, 2015). Nigella sativa and its important active component thymoquinone demonstrate an antihypercholesteremic effect by decreasing the level of HMG-CoA reductase enzyme, which is the rate limiting enzyme in cholesterol synthesis, to cause protective effects on dyslipidemia. Moreover, Nigella sativa is reported to display antihyperlipidemic properties by stimulating paraoxonase enzyme (PON1), which functions as an antioxidant, due to its LDL protective property against oxidation and its ability to neutralise radicals including hydrogen peroxide, to increase the activity of arylesterase, the protein indicator of the PON1 enzyme (S. Ahmad \& Beg, 2013; Türkoğlu et al., 2008).

It is claimed that the positive effects of $N$. sativa and its essential active component thymoquinone on cholesterol stem from their regulatory roles in antioxidant and gene metabolism. Their antioxidant properties are particularly important for the prevention of free radical formation due to diets with a high level of saturated fat and cholesterol, and for the prevention of oxidative stress and hypocholesteremia, because $N$. sativa is stated to have a protective role especially in LDL oxidation (S. Ahmad \& Beg, 2013; Türkoğlu et al., 2008).

\section{Antihypertensive Effects of Nigella sativa}

Another important risk factor for cardiovascular disease is hypertension. Arabs have used N. sativa seed together with honey or garlic for the treatment of hypertension in traditional medicine. It has been suggested that $N$. sativa extract reduces blood pressure in dogs. It has also been claimed that another antihypertensive effect of $N$. sativa oil might result from its diuretic effect (Salama, 2010).

An increase in oxidative stress is associated with the pathogenesis of hypertension. Blood pressure increases, depending on the imbalance between the antioxidant defence mechanism and free-radical production. An excessive increase in reactive oxygen products reduces the bioavailability of ni- tric oxide in endothelium dysfunction and increases the total peripheral resistance (Leong et al., 2013).

In human and animal studies, $N$. sativa and its active component thymoquinone is reported to contribute to a reduction in blood pressure and to reduce hypertension via various mechanisms, such as by antioxidant properties, calcium-channel blockage, and diuretic and hypotensive (soothing heartbeat) functions (A. Ahmad et al., 2013; Keyhanmanesh, Gholamnezhad, \& Boskabady, 2014).

In a study conducted on 70 healthy individuals with an age range of 34-63 years, a body weight range of $55-75 \mathrm{~kg}$, a systolic blood pressure range of 110-140 mm Hg and a diastolic blood pressure range of 60-90 $\mathrm{mm} \mathrm{Hg}$, individuals were divided into two groups - control and intervention. The intervention group was provided with $2.5 \mathrm{~mL} \mathrm{~N}$. sativa oil after meals, every 12 hours twice a day (5 $\mathrm{mL} /$ day total) for eight weeks. A significant decrease in diastolic and systolic blood pressure resulted in the group that was given $N$. sativa oil (Fallah Huseini et al., 2013). In another randomised controlled double-blind dose-response study that lasted 8 weeks, on 119 men between 35 and 50 years with mild hypertension, individuals were divided into three groups and were given a placebo, $100 \mathrm{mg}$ or $200 \mathrm{mg} \mathrm{N}$. sativa extract A significant decrease in the systolic and diastolic blood pressure was observed in the intervention group compared to initial levels and to those in individuals with the placebo; furthermore, extract usage decreased the diastolic and systolic blood pressure, depending on its dose. These results indicate that use of $N$. sativa extract for two months has a positive effect on lowering blood pressure in individuals with mild hypertension (Dehkordi \& Kamkhah, 2008).

\section{Type 2 Diabetes Mellitus and Nigella sativa}

Diabetes Mellitus is becoming more common worldwide; data from the IDF (International Diabetes Federation) indicate that the number of diabetic individuals will increase from 171 million individuals in 2001, to 366 million by 2030 . As a result of the metabolic dysfunction in DM, there is a higher risk of cardiovascular disease, dyslipidemia, infection, mortality and morbidity. Various treatment methods such as diet, changes in life style, biochemical and herbal treatment are used together or separately to control diabetes. Many countries mostly tend to use herb treatments 
J ournal abbreviation: J Food Health Sci

for diabetes, which are preferred as an alternative, and complementary medicine. Individuals generally tend to use herbs due to the side-effects of chemical medicines. The World Health Organisation (WHO) aims to convince researchers to research the positive and negative side effects of the potential therapeutic effects of herbs (Heshmati \& Namazi, 2015).

The effect mechanisms of $N$. sativa and its use in Type $2 \mathrm{DM}$ are as follows:

\section{Anti-diabetic Effect of Nigella sativa}

Nigella sativa and its active component thymoquinone have been shown to have positive effects in controlling glucose levels and lipid profiles in diabetics (Heshmati \& Namazi, 2015). Although the molecular mechanism of thymoquinone on insulin secretion has not been completely clarified, it is reported that thymoquinone causes an increase in glucose use by increasing the serum concentration, and decreasing a high levels serum glucose, and decreasing blood glucose by preventing gluconeogenesis (Benhaddou-Andaloussi et al., 2008; Heshmati \& Namazi, 2015; Kaatabi et al., 2015).

\section{Insulin Secretion}

Thymoquinone and other antioxidant components in $N$. sativa can increase insulin secretion by improving the energy metabolism of mitochondria and might also reduce liver injury, according to a study conducted on diabetic rats. The compounds also cause an increase in the insulin concentration by promoting the intracellular insulin receptor pathways (Heshmati \& Namazi, 2015). It has been suggested that thymoquinone and the other antioxidant components in $N$. sativa can activate the mitogen-activated protein kinases (MAPKs) and protein kinase $\mathrm{B}$ (PKB) pathways, which function in insulin sensitivity (Le et al., 2004).

\section{Gluconeogenesis}

Nigella sativa decreases gluconeogenesis, which contributes to hyperglycemia in diabetic individuals. Thymoquinone can reduce the expression of gluconeogenic enzymes (glucose 6-phosphatase and fructose 1,6-biphosphatase) and the production of hepatic glucose (Heshmati \& Namazi, 2015). Furthermore, N. sativa prevents gluconeogenesis by activating the protein kinases activated by adenosine monophosphate (AMPK) in liver and muscles (Heshmati et al., 2015).

\section{Glucose Absorption}

It has been shown that liquid intake of $N$. sativa extract reduces glucose absorption and inhibits the glucose carrier in diabetic rats. Another potential mechanism of action is that polyphenol components can suppress the properties of glucose absorption transport (Heshmati \& Namazi, 2015). Furthermore, thymoquinone is reported to have a curative effect in decreasing the oxidative stress that results from hyperglycaemia and protects $\beta$ cell integrity. As a consequence, the clinical use of thymoquinone can be effective in protecting $\beta$ cells against oxidative stress (Kaatabi et al., 2015). A double-blind placebo controlled study with 114 participants consisting of 63 men and 51 women, studied the effect of $N$. sativa supplement on glycaemic control and antioxidant capacity in Type 2 diabetic patients that used hypoglycaemic drugs; the intervention group was given $2 \mathrm{~g}$ /day $N$. sativa for one year. The study revealed considerable decreases in fasting blood glucose and $\mathrm{HbA} 1 \mathrm{c}$ levels of individuals; there were significant differences between groups and significant increases were observed in total antioxidant capacity, superoxide dismutase and glutathione levels of the group that took Nigella sativa powder compared to the control group. At the end of the treatment, insulin resistance decreased and $\beta$-cell activity increased compared to the level in individuals at the start of treatment (Kaatabi et al., 2015).

In a study in which individuals with Type $2 \mathrm{DM}$ were given $N$. sativa powder at a dose of 1,2 and $3 \mathrm{~g} /$ day, significant decreases were observed in insulin resistance and $\beta$-cell function indicators such as postprandial blood sugar, HbA1c, HOMA-IR, only in individuals who were supplied with $2 \mathrm{~g} N$. sativa powder per day. It was reported that the three different doses did not negatively affect the renal or hepatic functions of individuals during the study. The most effective does was determined to be $2 \mathrm{~g}$ and this might also confer positive benefits with hypoglycaemic agents (Bamosa et al., 2010). In another study, Type 2 DM patients were given $2 \mathrm{~g} /$ day $N$. sativa powder for one year and it was shown that HbAlc values decreased significantly in the intervention group (Bamosa, 2015). In another study that treated 60 individuals with insulin resistance who took hypoglycaemic drugs with 2.5 $\mathrm{mL} N$. sativa oil twice daily for 60 weeks, significant improvements were observed in TC, LDL and prepandial blood sugar levels. In addition, $N$. sativa oil is effective as an additional treatment in 


\section{J ournal abbreviation: J Food Health Sci}

individuals with insulin resistance. $N$. sativa is reported to have important effects especially in diabetic and dyslipidemic individuals (Najmi, Haque, Naseeruddin, \& Khan, 2008) and has also been shown to play an important role in the prevention of diabetic neuropathy in diabetic rats that were supplied with $50 \mathrm{mg} /$ day thymoquinone for 8 weeks (Omran, 2014).

\section{Anti-obesity effects of Nigella sativa}

Obesity is one of the most common health problems in all age groups worldwide. In recent years, herbal supplement use has assumed a place among the complementary diet-based and alternative treatment methods that are commonly used for weight loss (Hasani-Ranjbar, Jouyandeh, \& Abdollahi, 2013). Nigella sativa and its active substance thymoquinone show anti-obesity effects, due to their positive effects against cardiovascular disease, cancer, insulin sensitivity and their immune-modular effects (A. Ahmad et al., 2013; Vanamala, Kester, Heuberger, \& Reddivari, 2012). Although weight loss can occur in individuals, depending on decreases in insulin resistance, $N$. sativa can improve the lipid profile and blood glucose levels in individuals with DM after weight loss (Bamosa et al., 2010).

A $25 \%$ decrease in food intake was observed in rats that were fed with $N$. sativa oil by intragastric gavage for four weeks. Therefore, $N$. sativa oil might possess anorectic effects, and can cause a decrease in food intake and body weight, and possibly also improvements in lipid peroxidation and insulin sensitivity (Le et al., 2004). Another study demonstrated significant decreases in the body weight of diabetic rats following treatment with $300 \mathrm{mg}$ /day N. sativa extract for 30 days (Fararh, Ibrahim, \& Elsonosy, 2010).

Human studies in which the effect of $N$. sativa on obesity has been examined are limited. In a randomised controlled double-blind single study, 50 obese men were given $3 \mathrm{~g}$ /day Nigella sativa powder for 3 months and significant decreases in body weight, and the waist and hip circumference of individuals were found (Datau et al., 2010). However, $N$. sativa given to individuals with normal weight did not cause any significant change in the body weight (Qidwai, Hamza, Qureshi, \& Gilani, 2009). It is claimed that the consumption of $N$. sativa might be effective against obesity if used for a long period and in large amounts (Nader et al., 2010). Despite these results, more controlled intervention studies are required to understand better the effects of Nigella sativa on weight loss.

\section{Anticancer Effects of Nigella sativa}

Cancer is considered to be one of the health concerns that has rapidly become widespread. In 2013, half a million people died of cancer in America, and this rate is even higher in undeveloped countries and 8.2 million people died of cancer worldwide (WHO, 2015).

Nigella sativa and its active component thymoquinone are claimed to exhibit anticancer activity by causing the death of cancer cells or by preventing genetic changes in normal cells (Shafiq et al., 2014). Thymoquinone is considered to have antioxidant, anticancirogenic and antimutagenic properties. Many studies have shown that $N$. sativa and thymoquinone have antioxidant properties, and that they increase the activities of antioxidant enzymes such as superoxide, dismutase, catalase and glutathione peroxidase. Because oxidative stress has an effective role in the formation and development of different cancer types and thymoquinone increases the activity of the antioxidant enzymes mentioned above, the positive effects of $N$. sativa against cancer types possibly occurs via antioxidant effects (Badary, Taha, Gamal El-Din, \& Abdel-Wahab, 2003; Soumaya Bourgou et al., 2008; Khader, Bresgen, \& Eckl, 2010; Randhawa \& Alghamdi, 2011).

Over time, many different mechanisms of $N$. sativa seed function and its extract have been examined in different cancer types in both in vivo and in vitro studies. Nigella sativa has been shown to kill various cancerous cell types, and to cause an increase in macrophage cell number and activation (Ait Mbarek et al., 2007; Chehl, Chipitsyna, Gong, Yeo, \& Arafat, 2009; Darakhshan, Pour, Colagar, \& Sisakhtnezhad, 2015; El-Mahdy, Zhu, Wang, Wani, \& Wani, 2005; Shoieb, Elgayyar, Dudrick, Bell, \& Tithof, 2003; Yi et al., 2008; Yüncü et al., 2013).

\section{Lung cancer}

According to data from the American Cancer Association in 2012, lung cancer caused approximately $20 \%$ of total cancer deaths (1.59 million people), and this rate reached $27 \%$ in 2014 (Society, 2015). Nigella sativa supplement and $N$. sativa seed extract demonstrated cytotoxicity properties against lung sarcoma cells (Rooney \& Ryan, 2005). In particular, thymoquinone ob- 
J ournal abbreviation: J Food Health Sci

tained from $N$. sativa extract showed important anticancer properties against lung cancer cell numbers, and prevented cell proliferation by approximately 90\% (Shafiq et al., 2014).

\section{Breast cancer}

Although breast cancer is the primary causes of the death of females in undeveloped countries, it is the second most-important cause of death in developed countries (Shafiq et al., 2014). The liquid and alcoholic extracts of $N$. sativa have been shown to be effective in inactivating a breast cancer cell line (MCF-7), and have an effect on life span. Therefore, these extracts are proposed to represent a promising treatment for breast cancer (Farah \& Begum, 2002; Shafiq et al., 2014).

\section{Colon cancer}

Colon cancer causes the second-highest number of deaths among different cancers. According to statistics, more than half million people $(690,000)$ per annum die from this type of cancer (Society, 2015). It has been suggested that $N$. sativa can reduce DNA damage and prevent carcinogenesis in colon tissues exposed to toxic agents. A study that analysed the relationship between $N$. sativa and colon cancer demonstrated that thymoquinone inhibits the formation of 5-lipoxygenase products such as 5-hydroxeicosa-tetraenoic acids, which are necessary for colon cancer cells (ElMahmoudy et al., 2002). It has been shown that the effect of thymoquinone depends on the type of colon cancer cell; for instance, although it affects HCT-116 colon cancer cells by increasing apoptosis, it has no effect on HT-29 colon cancer cells (Abukhader, 2012; Rooney \& Ryan, 2005).

The summary of possible mechanisms of action of $N$. sativa in certain diseases are shown in Figure 2.

Figure 2. Possible effect mechanisms of Nigella sativa at certain diseases

\begin{tabular}{ll}
\hline Nigella sativa (Thymoquinone) & Disease \\
\hline Mechanism of action & Dyslipidaemia \\
\hline HMG-COA & Metabolic syndrome \\
Reductase activity arylesterase & \\
Antioxidant properties shown in cholesterol metabolism & Hypertension \\
\hline Reducing oxidative stress & \\
Blocking calcium channels & \\
Diuretic effect & Hyperglycaemia \\
Hypotension (soothing heartbeat) effects & Type 2 DM \\
\hline Increasing insulin sensitivity & \\
Blocking gluconeogenesis & \\
Decreasing glucose absorption & Obesity \\
Increasing insulin secretion & \\
Increasing $\beta$-cell proliferation & \\
\hline Dietary intake $~$ & \\
\hline Increasing the activity of antioxidant enzymes such as superoxide \\
dismutase (SOD), catalase (CAT) and glutathione peroxidase \\
(GPX)
\end{tabular}




\section{J ournal abbreviation: J Food Health Sci}

\section{Potential Toxicity of Nigella sativa}

Nigella sativa and its oil are reported to have a very low toxicity (Ali \& Blunden, 2003). The toxicological properties of thymoquinone were assessed in vitro and in vivo, by treating subjects with thymoquinone at doses between $20 \mathrm{mg} / \mathrm{kg}$ and $500 \mathrm{mg} / \mathrm{kg}$ (Abukhader, 2012; Ali \& Blunden, 2003 ) and death occurred due to other complications when the amount of thymoquinone reached $500 \mathrm{mg} / \mathrm{kg}$. Another study concerning the potential toxicity of $N$. sativa that was conducted on rats, by treating them with $2.5 \mathrm{~mL} / \mathrm{kg} / \mathrm{day} N$. sativa oil, resulted in no toxicity at the histopathological level (Yüncü et al., 2013).

\section{Conclusions}

Nigella sativa and its active component thymoquinone have positive effects on health, and their mechanism of action depends on the type of disease. The effective amount, form of intake (powder, extract, oil), and active component of $N$. sativa change according to the type of disease. Although the degree of effect and mechanism of action of $N$. sativa on some diseases have been demonstrated by in vivo and in vitro studies, insufficient studies exist in humans. Although at least 2 g $N$. sativa per day should be consumed in order to activate its antihyperlipidemic and antidiabetic effects, it is not realistically possible to propose this for cancer treatments, because the anticancer activities of $N$. sativa have been researched at the cellular level rather than via dose-response studies. Considering suggestions about the consumption amount of black cumin, its interaction with anticancer drugs should also be taken into consideration. We believe that the consumption of one heaped teaspoon of black cumin seed (approximately $2.5 \mathrm{~g}$ ) daily is beneficial for a healthy diet and to improve lipid profiles and blood glucose levels.

\section{References}

Abukhader, M. (2012). The effect of route of administration in thymoquinone toxicity in male and female rats. Indian Journal of Pharmaceutical Sciences, 74(3), 195.

Ahmad, A., Husain, A., Mujeeb, M., Khan, S. A., Najmi, A.K., Siddique, N. A., . . Anwar, F. (2013). A review on therapeutic potential of Nigella sativa: A miracle herb. Asian Pacific Journal of Tropical Biomedicine, 3(5), 337-352.
Ahmad, S., \& Beg, Z.H. (2013). Hypolipidemic and antioxidant activities of thymoquinone and limonene in atherogenic suspension fed rats. Food Chemistry, 138(2), 1116-1124.

Ait Mbarek, L., Ait Mouse, H., Elabbadi, N., Bensalah, M., Gamouh, A., Aboufatima, R., ... Dalal, A. (2007). Anti-tumor properties of blackseed (Nigella sativa L.) extracts. Brazilian Journal of Medical and Biological Research, 40(6), 839-847.

Akash, M., Rehman, K., Rasool, F., Sethi, A., Abrar, M., Irshad, A., . . . Murtaza, G. (2011). Alternate therapy of type 2 diabetes mellitus (T2DM) with Nigella (Ranunculaceae). Journal of Medicinal Plants Research, 5(31), 6885-6889.

Al-Naqeep, G., Al-Zubairi, A.S., Ismail, M., Amom, Z.H., \& Esa, N.M. (2011). Antiatherogenic potential of Nigella sativa seeds and oil in diet-induced hypercholesterolemia in rabbits. EvidenceBased Complementary and Alternative Medicine, 2011, 1-8.

Al-Mahasneh, M.A., Ababneh, H.A., \& Rababah, T. (2008). Some engineering and thermal properties of black cumin (Nigella sativa L.) seeds. International Journal of Food Science \& Technology, 43(6), 1047-1052.

Ali, B., \& Blunden, G. (2003). Pharmacological and toxicological properties of Nigella sativa. Phytotherapy Research, 17(4), 299305.

Badary, O.A., Taha, R.A., Gamal El-Din, A.M., \& Abdel-Wahab, M.H. (2003). Thymoquinone is a potent superoxide anion scavenger. Drug and Chemical Toxicology, 26(2), 87-98.

Bamosa, A.O. (2015). A review on the hypoglycemic effect of Nigella sativa and thymoquinone. Saudi Journal of Medicine and Medical Sciences, 3(1), 2.

Bamosa, A.O., Ali, B.A., \& al-Hawsawi, Z.A. (2002). The effect of thymoquinone on blood lipids in rats. Indian Journal of Physiology and Pharmacology, 46(2), 195201.

Bamosa, A.O., Kaatabi, H., Lebda, F.M., Elq, A.M.A., \& Al-Sultan, A. (2010). Effect of Nigella sativa seeds on the glycemic control 
J ournal abbreviation: J Food Health Sci

of patients with type 2 diabetes mellitus. Indian Journal of Physiology and Pharmacology, 54(4), 344-54.

Bayram, U.Ö.İ. (2012). Çörek Otunun (Nigella sativa) Kuzularda Besi Performans1, Baz1 Kan ve Rumen sıvısı Parametreleri Üzerine Etkisi. Kocatepe Veteriner Dergisi, 5(2), $27-33$

Benhaddou-Andaloussi, A., Martineau, L. C., Spoor, D., Vuong, T., Leduc, C., Joly, E., . . Arnason, J.T. (2008). Antidiabetic activity of Nigella sativa seed extract in cultured pancreatic $\beta$-cells, skeletal muscle cells, and adipocytes. Pharmaceutical Biology, 46(1-2), 96-104.

Botnick, I., Xue, W., Bar, E., Ibdah, M., Schwartz, A., Joel, D. M., . . . Lewinsohn, E. (2012). Distribution of primary and specialized metabolites in Nigella sativa seeds, a spice with vast traditional and historical uses. Molecules, 17(9), 10159-10177.

Bourgou, S., Ksouri, R., Bellila, A., Skandrani, I., Falleh, H., \& Marzouk, B. (2008). Phenolic composition and biological activities of Tunisian Nigella sativa L. shoots and roots. Comptes Rendus Biologies, 331(1), 48-55.

Bourgou, S., Pichette, A., Marzouk, B., \& Legault, J. (2010). Bioactivities of black cumin essential oil and its main terpenes from Tunisia. South African Journal of Botany, 76(2), 210-216.

Bourgou, S., Pichette, A., Marzouk, B., \& Legault, J. (2012). Antioxidant, anti-inflammatory, anticancer and antibacterial activities of extracts from Nigella sativa (black cumin) plant parts. Journal of Food Biochemistry, 36(5), 539-546.

Bulca, S. (2015). Çörek otunun bileşenleri ve bu yağın ve diğer bazı uçucu yağların antioksidan olarak gida teknolojisinde kullanımı. Journal of Adnan Menderes University, Agricultural Faculty, 11(2), 2936.

Burits, M., \& Bucar, F. (2000). Antioxidant activity of Nigella sativa essential oil. Phytotherapy Research, 14(5), 323-328.

Chehl, N., Chipitsyna, G., Gong, Q., Yeo, C.J., \& Arafat, H.A. (2009). Anti-inflammatory effects of the Nigella sativa seed extract, thymoquinone, in pancreatic cancer cells. HPB, 11(5), 373-381.

Darakhshan, S., Pour, A.B., Colagar, A.H., \& Sisakhtnezhad, S. (2015). Thymoquinone and its therapeutic potentials. Pharmacological Research, 95, 138-158.

Datau, E., Surachmanto, E., Pandelaki, K., \& Langi, J. (2010). Efficacy of Nigella sativa on serum free testosterone and metabolic disturbances in central obese male. Acta Medica Indonesiana, 42(3), 130-134.

Dehkordi, F.R., \& Kamkhah, A.F. (2008). Antihypertensive effect of Nigella sativa seed extract in patients with mild hypertension. Fundamental \& Clinical Pharmacology, 22(4), 447-452.

El-Mahmoudy, A., Matsuyama, H., Borgan, M., Shimizu, Y., El-Sayed, M., Minamoto, N., \& Takewaki, T. (2002). Thymoquinone suppresses expression of inducible nitric oxide synthase in rat macrophages. International Immunopharmacology, 2(11), 1603-1611.

El-Mahdy, M.A., Zhu, Q., Wang, Q.E., Wani, G., \& Wani, A.A. (2005). Thymoquinone induces apoptosis through activation of caspase- 8 and mitochondrial events in $\mathrm{p} 53$ null myeloblastic leukemia HL-60 cells. International Journal of Cancer, 117(3), 409-417.

Entok, E., Ustuner, M.C., Ozbayer, C., Tekin, N., Akyuz, F., Yangi, B., . . . Gunes, H. V. (2014). Anti-inflammatuar and antioxidative effects of Nigella sativa L.: 18FDG-PET imaging of inflammation. Molecular Biology Reports, 41(5), 28272834.

Fallah Huseini, H., Amini, M., Mohtashami, R., Ghamarchehre, M., Sadeqhi, Z., Kianbakht, S., \& Fallah Huseini, A. (2013). Blood Pressure Lowering Effect of Nigella sativa L. Seed Oil in Healthy Volunteers: A Randomized, Double-Blind, Placebocontrolled Clinical Trial. Phytotherapy Research, 27(12), 1849-1853.

Farah, I.O., \& Begum, R.A. (2002). Effect of Nigella sativa ( $N$. sativa $L$.) and oxidative stress on the survival pattern of MCF-7 breast cancer cells. Biomedical Sciences Instrumentation, 39, 359-364. 


\section{J ournal abbreviation: J Food Health Sci}

Fararh, K.M., Ibrahim, A.K., \& Elsonosy, Y.A. (2010). Thymoquinone enhances the activities of enzymes related to energy metabolism in peripheral leukocytes of diabetic rats. Research in Veterinary Science, 88(3), 400-404.

Forouzanfar, F., Bazzaz, B. S.F., \& Hosseinzadeh, H. (2014). Black cumin (Nigella sativa) and its constituent (thymoquinone): A review on antimicrobial effects. Iranian Journal of Basic Medical Sciences, 17(12), 929.

Güllü, E.B., \& Gülcan, A. (2013). Timokinon: Nigella sativa' nin Biyoaktif Komponenti. Kocatepe Veterinary Journal, 6(1), 51-61.

Hasani-Ranjbar, S., Jouyandeh, Z., \& Abdollahi, M. (2013). A systematic review of antiobesity medicinal plants-an update. Journal of Diabetes \& Metabolic Disorders, 12(1), 28.

Heshmati, J., \& Namazi, N. (2015). Effects of black seed (Nigella sativa) on metabolic parameters in diabetes mellitus: A systematic review. Complementary Therapies in Medicine, 23(2), 275-282.

Heshmati, J., Namazi, N., Memarzadeh, M.-R., Taghizadeh, M., \& Kolahdooz, F. (2015). Nigella sativa oil affects glucose metabolism and lipid concentrations in patients with type 2 diabetes: A randomized, double-blind, placebocontrolled trial. Food Research International, 70, 87-93.

Hosseinzadeh, H., \& Parvardeh, S. (2004). Anticonvulsant effects of thymoquinone, the major constituent of Nigella sativa seeds, in mice. Phytomedicine, 11(1), 5664.

Houcher, Z., Boudiaf, K., Benboubetra, M., \& Houcher, B. (2007). Effects of methanolic extract and commercial oil of Nigella sativa L. on blood glucose and antioxidant capacity in alloxan-induced diabetic rats. Pteridines, 18(1), 8-18.

Ibrahim, R.M., Hamdan, N.S., Ismail, M., Saini, S.M., Rashid, S.A., Latiff, L.A., \& Mahmud, R. (2014). Protective effects of Nigella sativa on metabolic syndrome in menopausal women. Advanced Pharmaceutical Bulletin, 4(1), 29-33.
Ilaiyaraja, N., \& Khanum, F. (2010). Nigella sativa L: a review of therapeutic applications. Journal of Herbal Medicine and Toxicology, 4(2), 1-8.

Kaatabi, H., Bamosa, A. O., Badar, A., Al-Elq, A., Abou-Hozaifa, B., Lebda, F., . . . AlAlmaie, S. (2015). Nigella sativa improves glycemic control and ameliorates oxidative stress in patients with type 2 diabetes mellitus: Placebo controlled participant blinded clinical trial. PloSone, 10(2), e0113486.

Kaatabi, H., Bamosa, A.O., Lebda, F.M., Al Elq, A.H., \& Al-Sultan, A.I. (2012). Favorable impact of Nigella sativa seeds on lipid profile in type 2 diabetic patients. Journal of Family and Community Medicine, 19(3), 155.

Kaya, M.S., Kara, M., \& Özbek, H. (2003). Çörek otu (Nigella sativa) tohumunun insan hücresel bağışıklık sisteminin $\mathrm{CD}^{3+}, \mathrm{CD}^{4+}$, $\mathrm{CD}^{8+}$ hücreleri ve toplam lökosit sayısı üzerine etkileri. Genel Tip Dergisi, 13, 109112.

Keyhanmanesh, R., Gholamnezhad, Z., \& Boskabady, M.H. (2014). The relaxant effect of Nigella sativa on smooth muscles, its possible mechanisms and clinical applications. Iranian Journal of Basic Medical Sciences, 17(12), 939.

Khader, M., Bresgen, N., \& Eckl, P. (2010). Antimutagenic effects of ethanolic extracts from selected Palestinian medicinal plants. Journal of Ethnopharmacology, 127(2), 319-324.

Kocyigit, Y., Atamer, Y., \& Uysal, E. (2009). The effect of dietary supplementation of Nigella sativa L. on serum lipid profile in rats. Saudi Medical Journal, 30(7), 893-896.

Latiff, L.A., Parhizkar, S., Dollah, M.A., \& Hassan, S.T.S. (2014). Alternative supplement for enhancement of reproductive health and metabolic profile among perimenopausal women: a novel role of Nigella sativa. Iranian Journal of Basic Medical Sciences, 17(12), 980.

Le, P., Benhaddou-Andaloussi, A., Elimadi, A., Settaf, A., Cherrah, Y., \& Haddad, P. (2004). The petroleum ether extracts of Nigella sativa seeds exert insulin sensitizing 
J ournal abbreviation: J Food Health Sci

and lipid lowering action in rats. Journal of Ethnopharmacology, 94(2-3), 251-259.

Leong, X.-F., Rais Mustafa, M., \& Jaarin, K. (2013). Nigella sativa and its protective role in oxidative stress and hypertension. Evidence-Based Complementary and Alternative Medicine, 2013, 1-9.

Lord, C., Sekerovic, Z., \& Carrier, J. (2014). Sleep regulation and sex hormones exposure in men and women across adulthood. Pathologie Biologie, 62(5), 302-310.

Mahdavi, R., Namazi, N., Alizadeh, M., \& Farajnia, S. (2015). Effects of Nigella sativa oil with a low-calorie diet on cardiometabolic risk factors in obese women: a randomized controlled clinical trial. Food \& function, 6(6), 2041-2048.

Mani, P., \& Rohatgi, A. (2015). Niacin therapy, HDL cholesterol, and cardiovascular disease: is the HDL hypothesis defunct? Current Atherosclerosis Reports, 17(8), 19.

Nader, M.A., El-Agamy, D.S., \& Suddek, G.M. (2010). Protective effects of propolis and thymoquinone on development of atherosclerosis in cholesterol-fed rabbits. Archives of Pharmacal Research (Seoul), 33(4), 637.

Najmi, A., Haque, S., Naseeruddin, M., \& Khan, R. (2008). Effect of Nigella sativa oil on various clinical and biochemical parameters of metabolic syndrome. Int J Diabetes Dev Ctries, 16, 85-87.

Omran, O. M. (2014). Effects of thymoquinone on STZ-induced diabetic nephropathy: an immunohistochemical study. Ultrastructural Pathology, 38(1), 26-33.

Paarakh, P.M. (2010). Nigella sativa Linn. A Comprehensive Review. 1(4), 409-429.

Qidwai, W., Hamza, H.B., Qureshi, R., \& Gilani, A. (2009). Effectiveness, safety, and tolerability of powdered Nigella sativa (kalonji) seed in capsules on serum lipid levels, blood sugar, blood pressure, and body weight in adults: results of a randomized, double-blind controlled trial. The Journal of Alternative and Complementary Medicine, 15(6), 639-644.
Ragheb, A., Elbarbry, F., Prasad, K., Mohamed, A., Ahmed, M.S., \& Shoker, A. (2008). Attenuation of the development of hypercholesterolemic atherosclerosis by thymoquinone. International Journal of Angiology, 17(04), 186-192.

Ramadan, M.F., \& Moersel, J.-T. (2004). Antiradical performance of some common and nontraditional vegetable oils. Inform, $15,553-555$.

Randhawa, M.A., \& Alghamdi, M.S. (2011). Anticancer activity of Nigella sativa (black seed) - a review. The American Journal of Chinese Medicine, 39(06), 1075-1091.

Razavi, B., \& Hosseinzadeh, H. (2014). A review of the effects of Nigella sativa L. and its constituent, thymoquinone, in metabolic syndrome. Journal of Endocrinological Investigation, 37(11), 1031-1040.

Rooney, S., \& Ryan, M. (2005). Modes of action of alpha-hederin and thymoquinone, active constituents of Nigella sativa, against HEp2 cancer cells. Anticancer Research, 25(6B), 4255-4259.

Salama, R. H. (2010). Clinical and Therapeutic Trials of Nigella sativa. TAF Preventive Medicine Bulletin, 9(5), 513-522.

Salem, M. L. (2005). Immunomodulatory and therapeutic properties of the Nigella sativa L. $\quad$ seed. International immunopharmacology, 5(13), 1749-1770.

Shafiq, H., Ahmad, A., Masud, T., \& Kaleem, M. (2014). Cardio-protective and anti-cancer therapeutic potential of Nigella sativa. Iranian Journal of Basic Medical Sciences, 17(12), 967.

Shahzad, F., \& Nasiruddin, M. (2011). Indigenous herbal product Nigella sativa proved effective as an anti-obesity therapy in metabolic syndrome. International Journal of Medicobiological Research, 1(3), 173176.

Shoieb, A.M., Elgayyar, M., Dudrick, P.S., Bell, J.L., \& Tithof, P.K. (2003). In vitro inhibition of growth and induction of apoptosis in cancer cell lines by thymoquinone. International Journal of Oncology, 22(1), 107-114. 


\section{J ournal abbreviation: J Food Health Sci}

Singh, S., Das, S., Singh, G., Schuff, C., de Lampasona, M.P., \& Catalán, C.A. (2014). Composition, in vitro antioxidant and antimicrobial activities of essential oil and oleoresins obtained from black cumin seeds (Nigella sativa L.). BioMed research international, 2014.

American Cancer Society (2015). Cancer Facts \& Figures 2014

http://www.cancer.org/research/cancerfacts statistics/cancerfactsfigures2014/ (available June, 2016).

Sultan, M.T., Butt, M. S., Anjum, F.M., Jamil, A., Akhtar, S., \& Nasir, M. (2009). Nutritional profile of indigenous cultivar of black cumin seeds and antioxidant potential of its fixed and essential oil. Pakistan Journal of Botany, 41(3), 1321-1330.

Tembhurne, S., Feroz, S., More, B., \& Sakarkar, D. (2014). A review on therapeutic potential of Nigella sativa (kalonji) seeds. Journal of Medicinal Plants Research, 8(3), 167-177.

Tüfek, N.H., Altunkaynak, M.E., Altunkaynak, B.Z., \& Kaplan, S. (2015). Effects of thymoquinone on testicular structure and sperm production in male obese rats. Systems Biology in reproductive Medicine, 61(4), 194-204.
Türkoğlu, S., Bulmuş, F. G., Parmaksiz, A., Özkan, Y., \& Gürsu, F. (2008). Metabolik sendromlu hastalarda paraoksonaz 1 ve arilesteraz aktivite düzeyleri. Fırat Tıp Dergisi, 13(2), 110-115.

Vanamala, J., Kester, A. C., Heuberger, A. L., \& Reddivari, L. (2012). Mitigation of obesitypromoted diseases by Nigella sativa and thymoquinone. Plant Foods for Human Nutrition, 67(2), 111-119.

WHO. (2015). Cancer.

http://www.who.int/mediacentre/factsheets /fs297/en/ (available June, 2016).

Yakup, K. (2007). Samsun yöresinde ve misir ülkesinde yetiştirilen çörekotu (Nigella sativa L.) Tohumlarinin antioksidan aktivite yönünden incelenmesi. Süleyman demirel Üniversitesi Fen Dergisi, 2(2). 197203.

Yi, T., Cho, S.-G., Yi, Z., Pang, X., Rodriguez, M., Wang, Y., . . . Liu, M. (2008). Thymoquinone inhibits tumor angiogenesis and tumor growth through suppressing AKT and extracellular signal-regulated kinase signaling pathways. Molecular Cancer Therapeutics, 7(7), 1789-1796.

Yüncü, M., Şahin, M., Bayat, N., \& İbrahim, S. (2013). Çörek otu yağının sıçan karaciğer gelişimine etkisi. Gaziantep Medical Journal, 19(3), 180-184. 